\title{
A Tribute to Loris Shano Russell, 1904-1998
}

\author{
KEVIN L. SEYMOUR
}

Department of Natural History, Royal Ontario Museum, 100 Queen's Park, Toronto, Ontario M5S 2C6 Canada; e-mail: kevins@ rom.on.ca

Seymour, Kevin L. 2004. A tribute to Loris Shano Russell. 1904-1998. Canadian Field-Naturalist 118(3): 451-464.

It was somewhat daunting to try to write the story of a man as accomplished as Loris Shano Russell. On one hand, it is relatively easy to record or list the numerous publications and awards. On the other hand, it is much harder to see through all of the accomplishments in order to glimpse something of the man himself. I got to know Loris only later in his life, as the one tasked with arranging his weekly visits to the Royal Ontario Museum (ROM), and so in this report I have relied on many who knew him earlier, in particular, John E. Storer.

Russell's accomplishments were many. He was one of the last of the "old school" of palaeontologists, those who studied and published original findings in geology, stratigraphy, and both fossil invertebrates and vertebrates: a broad concept rather foreign to most of us in today's specialized world. He was extremely organized, and was meticulous with everything he did, whether it was science, museology, ham and military radio operation, or administration. He was unfailingly polite and dignified, and always came to work wearing jacket and tie; about the worst name he ever called anyone in public was "stuffed shirt", a phrase he reserved for H. F. Osborn.

Loris died in July 1998 , in his $95^{\text {th }}$ year, and was predeceased by his beloved wife Grace, in March 1998. Their partnership of 60 years is the stuff of legends. They did everything together, from hosting museum dignitaries at their home, to attending antique markets, to working in the dirt and the heat in the badlands of Alberta collecting fossils (Figure 1). Grace never did learn very much about the fossils, but that didn't matter to her at all - she was there for, and with, Loris. When he was hospitalised in 1990, Grace visited several times a week, as long as the Wheel-Trans vehicles were available to take her there, as she was then not very mobile herself. Their separation at this time must have been very difficult for both of them. Grace was an out-

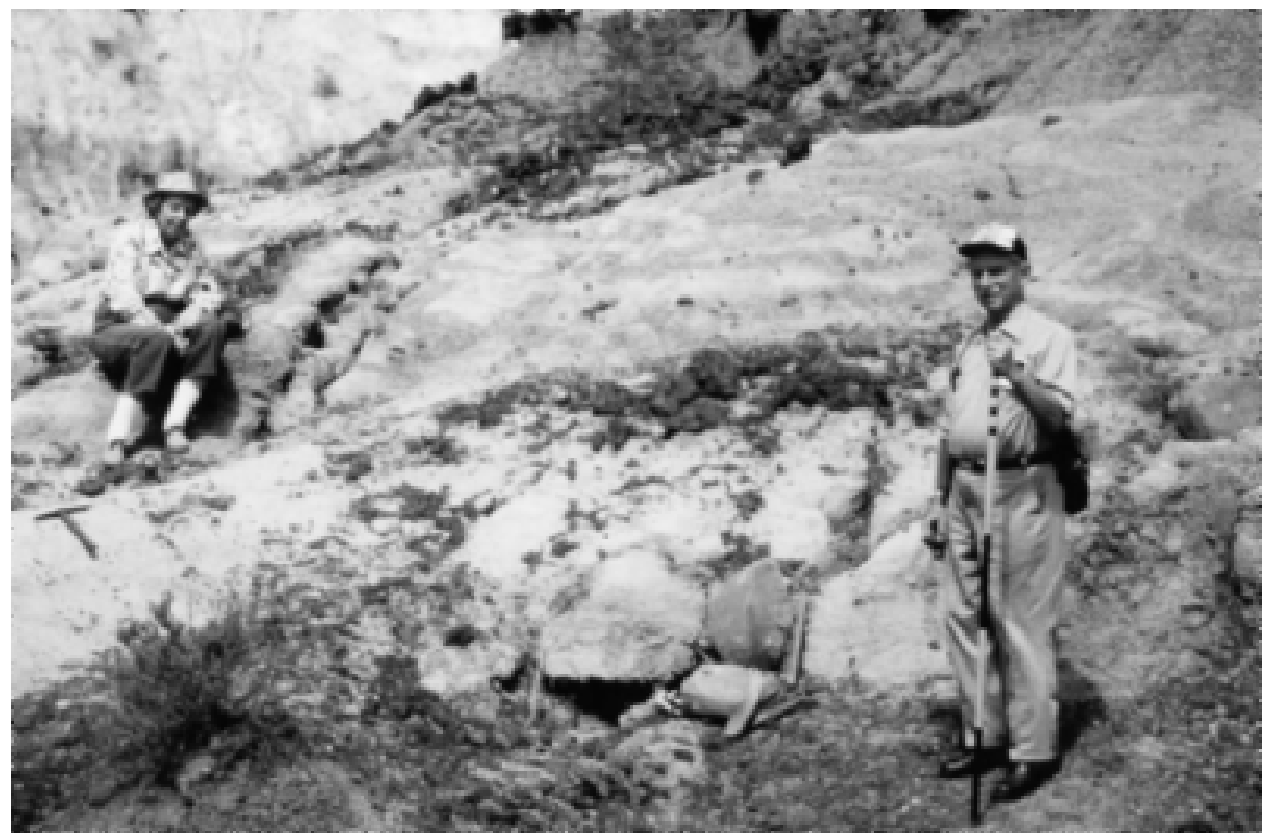

FIGURE 1. Grace and Loris Russell, 10 June 1986, in the Red Deer River valley, at the site where the holotype of Edmontosaurus regalis was collected by Levi and C. H. Sternberg in 1912. Photo by Maurice Stefanuk. (Photo courtesy ROM Archives). 
spoken fan of her husband, and she was as forthright with people as he was quiet and formal. Their differences were marked, yet their partnership flourished. They had no children, and the topic was never discussed with others. Many "Grace" stories exist; several are related in Churcher (2003). Francis Cook passed on the following story. At the NMC (National Museum of Canada, now the Canadian Museum of Nature) staff party for Loris when he was leaving and moving to the ROM, Grace invited everyone to visit them in their new quarters in Toronto and to use their swimming pool. Loris quietly yet respectfully deflected her enthusiasm by pointing out that they were moving to an apartment building and he was not sure that it included privileges for an infinite number of visitors to use the pool.

Loris Shano Russell was born in April 1904, in Brooklyn, New York. His parents were Matilda Shano of Newfoundland, and Milan Winslow Russell of New York. Loris' middle name came from his mother's maiden name, of course, and Loris told me that "Shano" was an anglicised version of the French "Chenaud". As for his unusual first name, Loris told me that his parents simply were looking for something different when they picked it; there was no family history to the name.

In 1908, when Loris was four, his family moved to Calgary, Alberta, where he grew up. He attended both public and high school in Calgary, and must have had a keen early interest in science, judging by early photos of him (Figures 2 and 3). He attended the University of Alberta, Edmonton, and graduated with a B.Sc. in Geology in 1927; however, he had already started publishing before graduation! He spent some time prospecting the Paskapoo Formation in Alberta near his family's home: his first two reviewed papers (published in 1926) are both on fossils of the Paskapoo. By this time he must have already encountered the Sternberg family of dinosaur collecting fame, as there is a 1923 photo of Loris excavating in the Red Deer River Valley, north of the Bleriot Ferry (Figure 4). Even at this early point in his career, his published papers were representative of his broad-ranging interests: one is on fossil molluscs, and the other on the fossil mammal Catopsalis. Fossils were not his only early interest, however. Before his first refereed papers on fossils, he had published a note on Alberta's birds in 1923.

At Princeton University, he studied under William Berryman Scott, the famous geologist and palaeontologist. W. A. Parks, then Head of the Department of Geology at the University of Toronto (UT), had wanted him to study at the UT, but Loris thought that it would be better to study with Scott, one of the very few European-trained professional vertebrate palaeontologists then teaching in North America. Loris was awarded his M.A. in 1929, and his Ph.D. in 1930, for a dissertation entitled "Stratigraphy and Paleontology of the Uppermost Cretaceous and Lower Tertiary Formations of Alberta", a copy of which is in the ROM

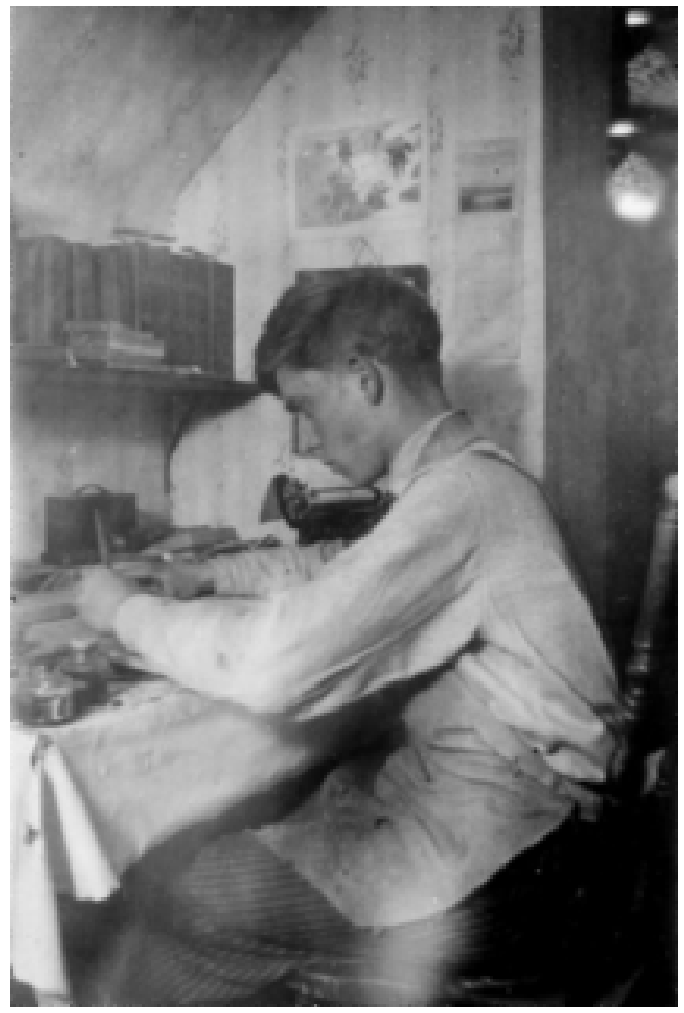

FIGURE 2. Loris Russell, 1920. Photographer unknown. (Photo courtesy ROM Archives).

library. By graduation he had published at least a dozen papers, including papers on subjects as diverse as fossil pelecypods, gastropods, fish, turtles, dinosaurs, marsupials and mammal tracks. These papers may have partly resulted from his summer work as a student assistant in 1925-1929 at the Research Council of Alberta in Edmonton.

After graduating from Princeton in 1930 at the age of 26, he moved to Ottawa and served as Assistant Palaeontologist for the Geological Survey of Canada (GSC) until 1936, and an Assistant Geologist in 1937. During this period (1930-1937), he published over two dozen papers, again on a wide variety of topics: besides the requisite geological and stratigraphic works, there were a number of papers on fossil mammals and fresh-water molluscs, with smaller contributions on turtles, plesiosaurs and dinosaurs. Because of the utility of molluses in biostratigraphy, many of his earlier works concentrated on these fossils. Of course his interests were not all palaeontological, and he joined the Ottawa Field-Naturalists' Club in 1933. He later became an honorary member of this organization in 1972, after serving as Vice-President for 1954-1956, and as President for 1957-1958. 


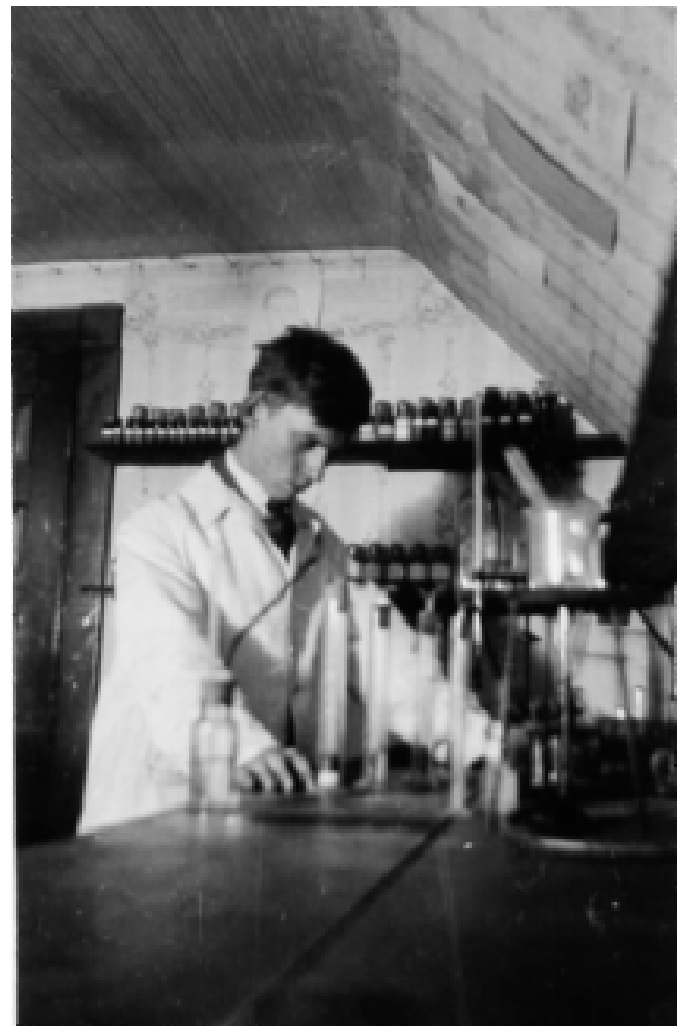

FIGURE 3. Loris Russell, 1922. Photographer unknown. (Photo courtesy ROM Archives).
During his initial period in Ottawa (1930-1937) Loris met his future wife and constant companion of 60 years, Grace. Grace Evelyn LeFeuvre was eight years younger than Loris. Her mother was born in Montreal of Irish stock, and her father had immigrated to Canada from Jersey, in the Channel Islands. Grace and Loris had met by arrangement of their mothers. While working at the GSC in Ottawa, where he could take Grace out on dates, Loris was offered the position of Assistant Director of the Vertebrate Section of the then separate Royal Ontario Museum of Palaeontology (ROMP), in 1937. This position came about due to the death of W. A. Parks in 1936, and Parks' protégé, Madeleine A. Fritz, simultaneously being appointed Assistant Director of the Invertebrate Section of ROMP. He considered turning down the offer, because he did not want to be far from Grace. The only solution was marriage, and his proposal was to the point: "I'm not going there without you". It appears he may have, at least briefly, because he moved to Toronto in 1937, and they were not married until 1938. Upon their marriage, Grace had to give up her nursing career, as only one income per household was allowed during the Depression.

With the Assistant Directorship at the ROMP came an Assistant Professorship at the UT, in Palaeontology. However, this work was interrupted by the Second World War. With his ability as a ham radio operator (Figure 5), he served from 1942 to 1945 in the Royal Canadian Signal Corps. He first learned this skill in 1922, an interest that he may have gotten from his father, who was a telegrapher for the railway (although his father had died earlier in 1911). At war's end, he was

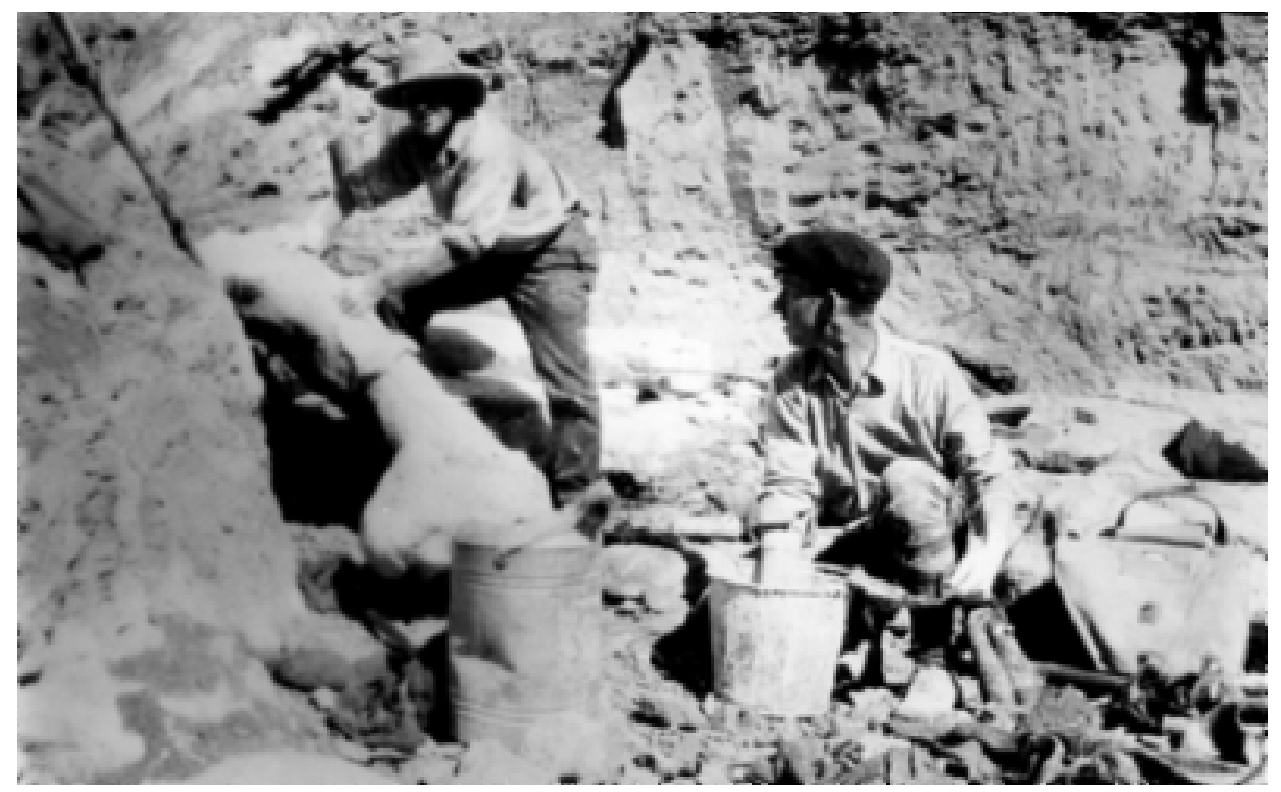

FIGURE 4. Loris Russell (right) and C. M. Sternberg (left) excavating an Edmontosaurus skeleton in the Red Deer River valley, 1923. Photo by J. E. Thurston. (Photo courtesy ROM Archives). 


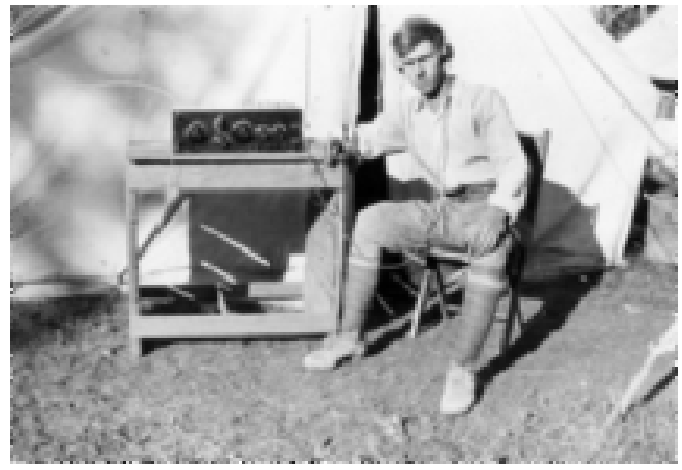

FIGURE 5. Loris Russell, circa 1922. Photographer unknown. (Photo courtesy ROM Archives).

transferred to the Reserve with the rank of Major. He continued an interest in communications, and collected early telegraph and other communications equipment, which since has been donated to the Museum of Science and Technology in Ottawa. In 1946 he was appointed Director of the ROMP and in 1948 Associate Professor at the UT. During 1937-1950 he continued his studies of fossil vertebrates, producing some two dozen papers on fishes, dinosaurs, creodonts, titanotheres, horses, and mastodons, as well as others on the geology of Alberta, fossil gastropods, eurypterids and even living rattlesnakes!

In 1950 came the offer to become Chief of the Zoology Section at the NMC, an offer he could not resist. $\mathrm{He}$ and Grace returned to Ottawa, and remained there for the next 13 years. In 1956 he was appointed Director of the Natural History Branch of the NMC (Figure 6), a post that he held until 1963. This time at the NMC was arguably the single most important part of his career as a research museum administrator, which he filled with steady competence, vision and perceptive guidance of staff activities. He hired several productive research and curatorial staff, including Wann Langston, Don McAllister and Arthur Clarke, who shared Loris' professional interests in vertebrate palaeontology, ichthyology, and malacology, respectively. He profoundly influenced the direction of the Canadian natural sciences even outside his own fields of interest. For instance, in 1955 he suggested to invertebrate zoologist E. L. Bousfield that, as a staff member of a national institution, he might consider field studies on the Canadian Pacific coast and break from a previous eight-year Ph.D. obsession with the Atlantic coast. This perceptive suggestion led to the discovery of a diverse, major fauna of amphipod crustaceans of which, during the next 30+ years, more than 200 species and higher taxa were newly described.

This period (1950-1963) must have been a very busy time for him, because in addition, in 1958 alone, he was appointed Acting Director of the Human History Branch at NMC, President of the Society of Verte- brate Paleontology, President of Section IV (Geology) of the Royal Society of Canada and he received an honorary LL.D. from the University of Alberta. He later became the President of the Canadian Museums Association (CMA) in 1961, and was awarded the Willet G. Miller Medal from the Royal Society of Canada (RSC) in 1959. With respect to the RSC, at the time of his death in 1998 he was the most senior member (by seven years over three other elderly fellows) of the entire RSC roster of approximately 1500 names, having been elected at the remarkable youthful age of 32 (in 1936), and with 62 years of mostly active participation in this select group of Canadian scientists.

While at the NMC, Loris always had the deep respect of the staff, even though he had a bit of difficulty adjusting to the fact that they were no longer required to work Saturday mornings, as they had when he joined the GSC in the 1930s. When the NMC staff complained in winter about the cold and drafty Victoria Memorial Museum building where they all had offices, Loris quietly remarked that when Dr. Rand (Chief Zoologist from 1942-1947 and a very productive staff member) was there, he just put on an overcoat and went on working. During 1950-1963, he wrote nearly 60 papers, with a broad range of topics: geology, eurypterids, molluscs, fishes, acanthodians, champsosaurs, carnivores, horses, and rabbits. Also during this time he produced more synthetic papers that included discussions of mammalian migrations, continental zoology of the North American Pleistocene, the geological record of evolution, as well as some on museology. These later papers were unlike anything he had written before, and spoke of a greater involvement in the museum community. Examples are several reports on television in museums, out-of-doors museums, plastics in the museum, and historical conservation along the St. Lawrence Seaway.

Loris was intrigued by museums and was involved in the earliest days of the CMA. He was a forwardthinking museologist, whose central tenet could be summed up as: "Museums are doing their job when they are telling stories to the public". This was not the prevailing thought in the 1960 s, when the object was supposed to speak for itself, aided by lighting and gadgets, but it seems to be the popular notion once again, where story-centred galleries are becoming common.

Although Loris may well have had a lifelong interest in material culture, it was during this period that this interest blossomed; being the President of the CMA from 1961-1963 and Acting Director of the Human History Branch of the NMC no doubt spurred it on. Constrained by a lack of time to do much palaeontological research while handling administration, Loris decided he would try to apply scientific methods to some research in material history, as an experiment. He chose oil lamps as a subject for research, perhaps as a manifestation of industrial development coupled with social history, and it kept him "occupied and 
broke" for years. Loris and Grace visited antique shops together, often in small towns on their way to do palaeontological fieldwork. Some of these adventures are described in his 1969 Rotunda article. His habit of meticulously documenting and labelling everything, plus his deep-seated love of a good story (he claimed it came from growing up in the "Wild West"), put him in the position to do ground-breaking research in material culture. Loris developed a superb collection of well-documented lamps, which were later kept in glass display cases in their Toronto apartment; these have since been donated to the ROM. Several books, A Heritage of Canadian Light (1968), Handy Things to Have Around the House (1979), and Every Day Life in Colonial Canada (1980) resulted from this research. These are still standard references today; indeed, $A$ Heritage of Light was reprinted in February 2003 by the University of Toronto Press. He became a speaker in demand at various material culture conferences over the next few decades.

In 1963, Loris left NMC under some controversy. Upheaval in the administrative ranks of the NMC made for some messy politics, which Loris did not care for. Returning to Toronto and the ROM, he became the Head of the Life Sciences Division at the ROM, and a year later, he filled the newly created position of Chief Biologist. By that time, the five former Royal Ontario Museums (zoology, palaeontology, mineralogy, geology and archaeology) had been amalgamated into a single institution under one Director. Much of his continued success at ROM was due to Anne Liebeck, Loris' able secretary (Figure 7). She guarded the entrance to Loris' office and answered his telephone, so that he could continue his studies virtually without interruption. In 1964, he received a Diploma with Distinction from the Museums Association of Great Britain. With Loris' return to Toronto came a professorship in the Department of Geology at the UT. He took on three Ph.D. students before retiring: John Storer (graduated in 1970), and Paul Ramaekers and Mark Wilson, both of whom graduated in 1974. Loris officially retired in 1970, when he was appointed Professor Emeritus at the UT in 1970, and Honorary Curator at the ROM in 1971. Loris continued to serve the scientific community after retirement - he was elected in 1971 to the Presidency of the Royal Canadian Institute, and in 1972 to the Presidency of the International Palaeontological Union, a four-year term. He published another 36 papers during this time, with a familiar breadth of topics. Several papers hinted of things to come: his museology papers concentrated on lighting and lamps, and his articles on "Tertiary Mammals of Saskatchewan, Part 1" and "The Great Saskatchewan Mouse Mine" began a series of papers on these important faunas from Saskatchewan. As well, Loris' paper on "Body temperature of dinosaurs and its relationship to their extinction" in 1965 marks the first, and often overlooked, discussion in the Eng-

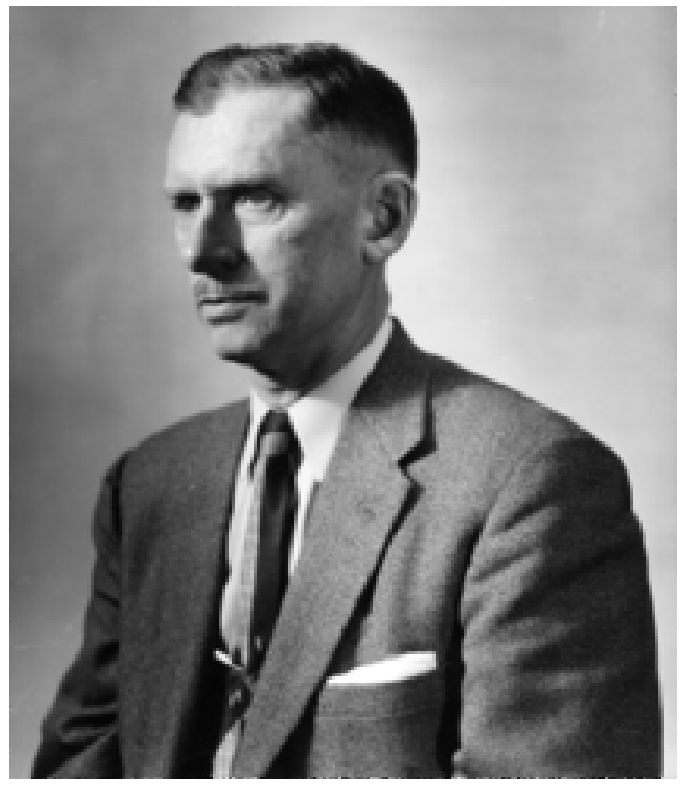

FIGURE 6. Loris Russell, 8 November 1956, as Head of the Department of Natural History, National Museum of Canada. Photographer unknown. (Photo courtesy of the CMN Archives, negative \#J4171).

lish scientific literature of what was later to become a revolution in thinking: dinosaurs as active "warmblooded" animals. Grace often cited this paper as one of the reasons she was so proud of "her hubby". It was not a secret wish of Loris' that perhaps Bob Bakker and John Ostrom (the oft-cited originators of this hypothesis) and others might have given him more credit for this early insightful work.

His official retirement only meant less administration. He continued fieldwork in Alberta each summer with Grace and others, well into his eighties, until at least 1988, supported by NSERC (Natural Science and Engineering Research Council of Canada) grants. These grants and the subsequent fieldwork meant that he actively published papers until about 1990, with over 40 contributions since retirement. He continued to come into his ROM office daily from 1971 until about 1990, when he first entered hospital for a hipreplacement operation. He never left hospitals after the first operation. From 1994 until 1997, while still wheelchair-bound due to a second failed hip replacement operation, I arranged that he visit ROM one day a week (except during winters) using Wheel-Trans services. During these visits he worked on his last manuscript, concerning the biostratigraphy of the Horseshoe Canyon Formation. Although this paper was never published, staff at the Royal Tyrrell Museum of Palaeontology and the Canadian Museum of Nature plan to publish a paper in the near future on the biostratigraphy of the Horseshoe Canyon Formation rec- 


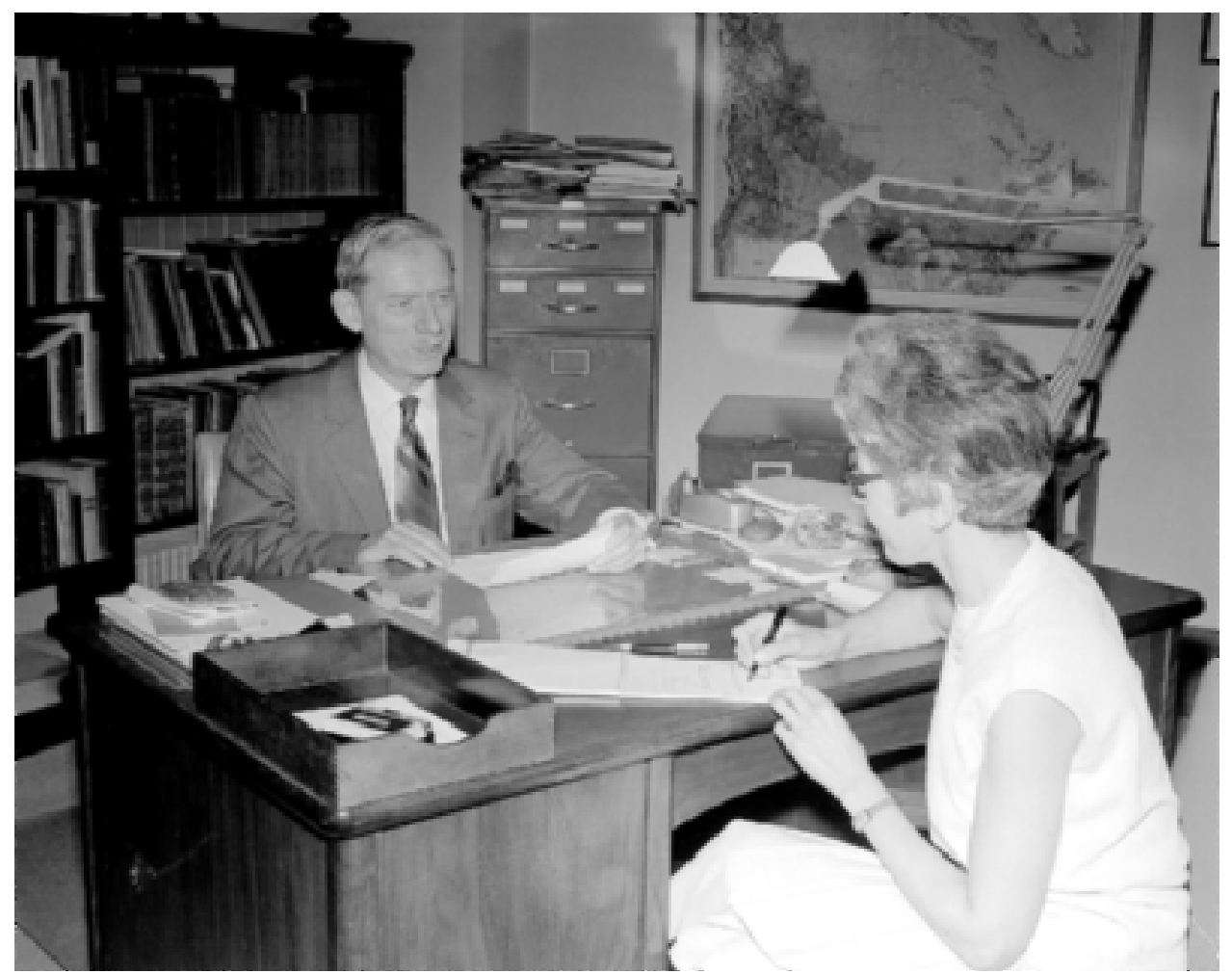

FiguRE 7. Loris Russell and Anne Liebeck at ROM, 1971. Photo by L. R. Warren. (Photo courtesy ROM Photography).

ognizing Loris' essential contributions by including him as a posthumous co-author. Many important palaeontological contributions came from this post-retirement period, for example, the series of papers on the Tertiary Mammals of Saskatchewan (Parts 2 through 7). More awards came late in his life, in particular, the Canadian Silver Jubilee Medal in 1978, the Billings Medal from the Geological Association of Canada in 1984 and the Romer-Simpson Medal from the Society of Vertebrate Paleontology in 1992.

As Tokaryk (1998) noted, much of Loris' scientific work was accomplished solo, judging by the rarity of co-authored publications (only 10 out of more than 200 papers published over 70 years have co-authors). This was partly due to the paucity of other Canadian palaeontologists at the time (although he was ably assisted, or worked with, a number of others in the field), but mostly to do with the fact that he could handle both the geological and palaeontological parts of his chosen projects. A measure of the impact of his work can be taken by counting the number of his papers that were abstracted in the German abstract series Palaeontologishes Zentralblatt (after 1950 called Zentralblatt für Geologie und Paläontologie, Teil 2) or Neues Jahrbuch für Mineralogie, Geologie und Paläontologie (after 1942 called Zentralblatt für Mineralogie, Geologie und Paläontologie). Between 1927 and 1989, I found 68 Russell papers had been abstracted, by a total of 15 different reviewers (besides those who wrote anonymously), although more than half of this total were written by Jaworski or Wenz on molluses and von Huene, primarily on dinosaurs.

He was an adventuresome scientist, always willing to strike off in a new direction. While on holiday with Grace in Hawaii, he collected some fossil land snails at the famous Diamond Head locality of picture postcard fame. A drawer of this material remains at the ROM, labelled and researched, although he never did publish on them. Nor was he afraid of being wrong, or did he mind greatly if new research invalidated a few of his ideas: that was the way science worked. As long as the work was careful and the facts were straight, then this was fine with him, an admirable quality in a scientist!

Another quality that many people noticed in Loris was his phenomenal memory for field localities. He really could find fossil localities he hadn't seen in 40 years. His successes were legion, so the few exceptions stood out, and yet all of these exceptions seemed to have complicating factors. For instance, he was frus- 
trated about not being able to relocate the Calgary Paskapoo Formation localities he collected as a young student, only to realise that housing developments had probably covered the area. He tried many times to find Brown's (1914) Erickson's Landing locality. Although in Russell (1929) he reported relocating this locality, Krause (1978) expressed some doubt about this, and Loris must have harboured some doubts himself. Eventually, as reported by Fox (1990), Loris concluded that there was no way to determine from exactly which level the slump block containing the fossils was derived, and so he never was able to collect significant additional material.

Certainly Loris had a happy outlook on life, and he taught by example, both in the field and in the laboratory. He was an inspiring influence to all who worked with him. He was also the kind of person who would retreat to his workshop to solve design problems, perhaps a legacy of his ham radio days. He designed a unique machine for feeding a thin stream of washed fossil concentrate onto a rubber belt (Figure 8), the movement of which was controlled by a foot pedal. The belt passed under a microscope, allowing him to focus on, and select out, any fossils of interest with his free hands. Uninteresting concentrate rotated off the belt and into a box of scrap. We have preserved this machine at the ROM; perhaps someday others will use it. It was known by words beginning with the letter ' $\mathrm{M}$ ', such as 'Miraculous Moving Miocene Mouse Machine'. For work on site at the Kleinfelder Farm locality in Saskatchewan (appropriately enough called the 'Mouse Mine'), he also designed two rotary sieves, described in his 1970 Rotunda article.

Although Dr. Russell (as he was known) seemed a little stiff and intimidating with some people, he actually had a wry yet somewhat playful sense of humour that surfaced quietly with those he knew well. He was quite amused by the ironies of growing older. On a couple of occasions he observed: "We used to call Scott and Osborn and their generation the 'old boys', and look how things have turned out now". He would tell the story of being a young geological assistant in the 1920s when one evening he got some sort of buzzing insect stuck in his ear. On asking another assistant, who was a medical student, what he should do, he was told "Well, take it out of there!". Loris' father was a religious fundamentalist, so Loris learned the Bible while young. In his later years he was not religious, but appreciated and was amused by the fundamentalist side of Western life. He liked to recount Charlie Sternberg's remark "My, aren't we clever", when William "Bible Bill" Aberhart (Dean of the Calgary Prophetic Bible Institute) stated in a radio sermon that palaeontologists were actually manufacturing fake dinosaur bones in seclusion in the badlands. At a gathering for an NMC staff member about to be married, Francis Cook noticed Loris was drinking milk, whereas the rest of those in attendance were

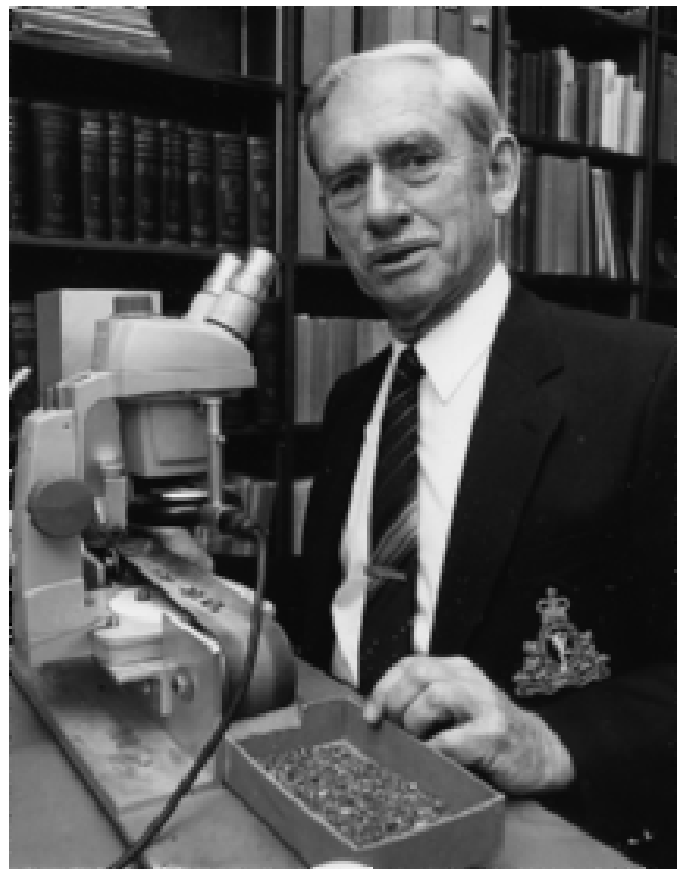

FIGURE 8. Loris Russell with the Marvellous Moving Miocene Mouse Machine, 1981. Photographer unknown. (Photo courtesy ROM Photography).

not. The host, when this was mentioned, assured Francis that Loris was drinking milk only because he had an ulcer, but that he had laced it with whiskey, thereby obeying doctor's orders yet joining his colleagues. He always found his own way.

Several obituaries already have been written (Harington 1998; Shaul 1998; Sues 1998; Tokaryk 1998; Churcher 2003), and two appreciations (Swinton 1976; Churcher 1993), with many additional biographical details. Swinton (1976) also included a fairly complete Russell bibliography up to 1976. A more complete bibliography is included herein.

The Russell papers, including diaries, field notes, photos, films (several different kinds), correspondence and other records, were inventoried by Boden (1999) and Baltovich (2001), and are placed in the ROM archives. His slides and reprints of scientific articles are stored in the Section of Palaeobiology, Department of Natural History, ROM. Hopefully, someone in the future will take advantage of this material (particularly the diaries and films) and write a book on Loris Russell.

\section{Acknowledgments}

For personal information: John Storer (Yukon Department of Tourism and Culture, Whitehorse), Rufus Churcher (retired from the UT), Tony Flynn (Seneca College, Toronto) and Grace's niece Barbara 
Rager, of Ottawa. Francis Cook, E. L. Bousfield, Dick Harington and Richard Day, past and present NMC (now CMN) staff, read an earlier draft and contributed many useful comments and additions. In particular, Richard Day located many bibliographic citations for abstracts (and this started me looking for more!). For salvaging the Russell diaries for the ROM: Tony Flynn. For access to the ROM Archives, and for their interest in the Russell papers: Julia Matthews and Sharon Hick. For bibliographic assistance: Arthur Smith. For photographic assistance: Alison Murray and Peter Fenton. I would like to most sincerely thank all of these people for their assistance with this tribute; without them it simply would not have been completed.

\section{Documents and Literature Cited}

Baltovich, R. 2001. Report on inventory project [addendum]: the Loris Shano Russell papers. Unpublished report, 18 pages. [on file in ROM Library and ROM Section of Palaeobiology, Department of Natural History].

Boden, S. 1999. Report on inventory project: the Loris Shano Russell papers. Unpublished report, 31 pages. [on file in ROM Library and ROM Section of Palaeobiology, Department of Natural History].

Brown, B. 1914. Cretaceous-Eocene correlation in New Mexico, Wyoming, Montana, Alberta. Geological Society of America Bulletin 25: 355-380.

\section{Loris Shano Russell Bibliography}

\section{Compiled by Kevin L. Seymour}

Included are books, book reviews, scientific articles and those on material culture, but probably not all abstracts. Abstracts or reviews of Russell's work that were written by others are not included, but many are on file in the Section of Palaeobiology, Department of Natural History, ROM. Within any year, the articles are not necessarily listed in strict chronological order. For those papers with co-authors, all authors are listed; if no author is listed, the paper was authored solely by L. S. Russell. Copies of all publications are on file in the Section of Palaeobiology, Department of Natural History, ROM.

1923 Alberta and its birds. Bird-Lore 25(5): 348-350.

1926a Technique. American Journal of Science 11: 498-500.

1926b A new species of the genus Catopsalis Cope from the Paskapoo Formation of Alberta. American Journal of Science 12: 230-234.

1926c Mollusca of the Paskapoo Formation in Alberta. Transactions of the Royal Society of Canada, Third Series, 20 (Section 4): 207-220, Plates 1-3.

1928a Didelphiidae from the Lance beds of Wyoming. Journal of Mammalogy 9: 229-232.

1928b A new fossil fish from the Paskapoo beds of Alberta. American Journal of Science 15: 103-107.

1928c R. L. Rutherford and L. S. Russell. Mammal tracks from the Paskapoo beds of Alberta. American Journal of Science 15: 262-264.
Churcher, C. S. 1993. Loris Shano Russell. (Eulogy for) Romer Simpson Prize. Society of Vertebrate Paleontology News Bulletin 157: 26-27.

Churcher, C. S. 2003. Loris Shano Russell, 1904-1998. Proceedings of the Royal Society of Canada for 2001, Sixth series, 12: 265-270.

Fox, R. C. 1990. The succession of Paleocene mammals in western Canada. Pages 51-70 in Dawn of the Age of Mammals in the northern part of the Rocky Mountain Interior, North America. Edited by T. M. Bown and K. D. Rose. Geological Society of America Special Paper 243.

Harington, C. R. 1998. In memoriam: Loris Shano Russell 1904-1998. Trail and Landscape 32(4): 166-169.

Krause, D. W. 1978. Paleocene primates from western Canada. Canadian Journal of Earth Sciences 15: 1250-1271.

Russell, L. S. 1929. Paleocene vertebrates from Alberta. American Journal of Science 17: 162-178.

Shaul, S. 1998. Shining a light on the dim past: lives lived Loris Shano Russell. Globe and Mail, August 12: A18.

Sues, H.-D. 1998. Loris Shano Russell, 1904-1998. Society of Vertebrate Paleontology News Bulletin 174: 81-83.

Swinton, W. E. 1976. Loris Shano Russell: an appreciation. Pages 3-13 in Athlon: essays on palaeontology in honour of Loris Shano Russell. Edited by C. S. Churcher. Royal Ontario Museum, Life Sciences Miscellaneous Publication.

Tokaryk, T. T. 1998. One of the last of the early giants. Geology Today 14(6): 226-228. 1928d The genera Kindleia and Stylomyleodon. American Journal of Science 15: 264.

1929a Paleocene vertebrates from Alberta. American Journal of Science 17: 162-178.

1929b The validity of the genus Stylomyleodon. American Journal of Science 17: 369-371.

1929c Upper Cretaceous and Lower Tertiary Gastropoda from Alberta. Transactions of the Royal Society of Canada, Third Series, 23 (Section 4): 81-90, Plate 1.

1930a Early Tertiary mammal tracks from Alberta. Transactions of the Royal Canadian Institute 17: 217-221, Plates 7-11.

1930b A new species of Aspideretes from the Paskapoo Formation of Alberta. American Journal of Science 20: 27-32.

1930c Upper Cretaceous dinosaur faunas of North America. Proceedings of the American Philosophical Society 69: 133-159.

1930d Fresh-water plesiosaurs. Bulletin of the Geological Society of America 41: 198. [Abstract].

1930e Stratigraphy and paleontology of the Uppermost Cretaceous and Lower Tertiary Formations of Alberta. Ph.D. thesis, Princeton University, 91 pages.

1931a Mollusca from the Upper Cretaceous and Lower Tertiary of Alberta. Transactions of the Royal Society of Canada, Third Series, 25 (Section 4): 9-19, Plates 1-2.

1931b Fresh-water plesiosaurs. Pan-American Geologist 53: 153. [Abstract].

1931c Fresh-water plesiosaurs. Canadian Field-Naturalist 45: 135-137. 
1931d Early Tertiary Mollusca from Wyoming. Bulletins of American Paleontology 18(64): 1-38, Plates 1-4.

1931e Devonian fishes of eastern Canada. Bulletin of the Geological Society of America 42:361. [Abstract]

1932a Mollusca from the McMurray Formation of Northern Alberta. Transactions of the Royal Society of Canada, Third Series, 26 (Section 4): 1-7, Plate 1.

1932b The Cretaceous-Tertiary transition of Alberta. Transactions of the Royal Society of Canada, Third Series, 26 (Section 4): 121-156.

1932c New data on the Paleocene mammals of Alberta, Canada. Journal of Mammalogy 13: 48-54.

1932d On the occurrence and relationships of the dinosaur Troödon. Annals and Magazine of Natural History, Series 10, 9: 334-337.

1932e New species of Mollusca from the St. Mary River Formation of Alberta. Canadian Field-Naturalist 46: 80-81.

1932f Stratigraphy and structure of the eastern portion of the Blood Indian reserve, Alberta. Geological Survey of Canada, Summary Report 1931B: 26-38.

1932g Fossil non-marine Mollusca from Saskatchewan. Transactions of the Royal Canadian Institute 18: 337-341, Plate 1.

1933a A new species of Merychippus from the Miocene of Saskatchewan. Canadian Field-Naturalist 47: 11.

1933b L. S. Russell and R. T. D. Wickenden. Discovery of an Upper Eocene mammalian fauna in Southern Saskatchewan. Bulletin of the Geological Society of America 44: 199. [Abstract].

1933c Peking Man. The Civil Service Review 5: 104.

1933d L. S. Russell and R. T. D. Wickenden. An Upper Eocene vertebrate fauna from Saskatchewan. Transactions of the Royal Society of Canada, Third Series, 27 (Section 4): 53-66, Plate 1.

1933e L. S. Russell and R. T. D. Wickenden. Upper Eocene vertebrate fauna from Saskatchewan, Canada. Proceedings of the Royal Society of Canada, Third Series, 27 (Appendix B): 143. [Abstract by title only].

$1933 f$ Revision of the Lower Oligocene vertebrate fauna of the Cypress Hills, Saskatchewan. Proceedings of the Royal Society of Canada, Third Series, 27 (Appen$\operatorname{dix}$ B): 144. [Abstract by title only].

1933 g Early Tertiary mammal tracks from Alberta. Palaeontologisches Zentralblatt 2: 321. [Abstract].

1934a Reclassification of the fossil Unionidae (fresh-water mussels) of Western Canada. Canadian Field-Naturalist 48: 1-4.

1934b Pleistocene and post-Pleistocene molluscan faunas of Southern Saskatchewan. Canadian Field-Naturalist 48: 34-37.

1934c New fossil fresh-water Mollusca from the Cretaceous and Paleocene of Montana. Journal of the Washington Academy of Sciences 24: 128-131.

1934d Discovery of Middle Eocene Mammalia in British Columbia. Proceedings of the Geological Society of America for 1933: 368. [Abstract].

$1934 \mathrm{e}$ Restoration of the horned dinosaur Chasmosaurus. Proceedings of the Geological Society of America for 1933: 368. [Abstract].

1934f Revision of the Lower Oligocene vertebrate fauna of the Cypress Hills, Saskatchewan. Transactions of the Royal Canadian Institute 20: 49-67, Plates 7-10.

1934g Fossil turtles from Saskatchewan and Alberta. Proceedings of the Royal Society of Canada, Third Series, 28 (Appendix C): 113. [Abstract]. 1934h Fossil turtles from Saskatchewan and Alberta. Transactions of the Royal Society of Canada, Third Series, 28 (Section 4): 101-110, Plates 1-6.

1934i An Upper Eocene vertebrate fauna from Saskatchewan. Palaeontologisches Zentralblatt 5: 43. [Abstract].

1935a A Middle Eocene mammal from British Columbia. American Journal of Science 29: 54-55.

1935b Musculature and function in the Ceratopsia. Bulletin of the National Museum of Canada 77: 39-48.

1935c Fauna of the Upper Milk River beds, Southern Alberta. Proceedings of the Royal Society of Canada, Third Series, 29 (Appendix B): 99. [Abstract].

1935d Fauna of the Upper Milk River beds, Southern Alberta. Transactions of the Royal Society of Canada, Third Series, 29 (Section 4): 115-128, Plates 1-5.

1935 e F. J. Fraser, F. H. McLearn, L. S. Russell, P. S. Warren, and R. T. D. Wickenden. Geology of Southern Saskatchewan. Geological Survey of Canada Memoir 176: 1-137, Plates 1-5.

1935f A Middle Eocene mammal from British Columbia. Palaeontologisches Zentralblatt 6: 378. [Abstract].

1935g Plesiosaur from the Upper Cretaceous of Manitoba. Proceedings of the Geological Society of America for 1934: 378. [Abstract].

1935h Dinosaur restoration group in the National Museum of Canada. Proceedings of the Geological Society of America for 1934: 378. [Abstract].

1935i A plesiosaur from the Upper Cretaceous of Manitoba. Journal of Paleontology 9: 385-389, Plates 44-46.

$1935 \mathrm{j}$ Revision of the Lower Oligocene vertebrate fauna of the Cypress Hills, Saskatchewan. Palaeontologisches Zentralblatt 7: 49. [Abstract].

1936a Oil and gas possibilities along Milk River, southeastern Alberta. Geological Survey of Canada Paper 36-12: 1-24.

1936b Second multituberculate from the Belly River Formation of Alberta. Proceedings of the Geological Society of America for 1935: 403. [Abstract].

1936c New and interesting mammalian fossils from western Canada. Transactions of the Royal Society of Canada, Third Series, 30 (Section 4): 75-80, Plate 1.

1936d A plesiosaur from the Upper Cretaceous of Manitoba. Palaeontologisches Zentralblatt 8: 327. [Abstract].

1937a Revision of the geology of the southern Alberta plains. Transactions of the Canadian Institute of Mining and Metallurgy 40: 185-196.

1937b Preliminary Report. Del Bonita area, southern Alberta. Geological Survey of Canada, Paper 37-10: 1-12.

1937c L. S. Russell and J. C. Sproule. Preliminary Report. Geology of the vicinity of Taber, Alberta. Geological Survey of Canada, Paper 37-14: 1-7.

1937d New non-marine Mollusca from the Upper Cretaceous of Alberta. Proceedings of the Royal Society of Canada, Third Series, 31 (Appendix B): 143. [Abstract].

1937e New non-marine Mollusca from the Upper Cretaceous of Alberta. Transactions of the Royal Society of Canada, Third Series, 31 (Section 4): 61-67, Plate 1.

1937f Fossil turtles from Saskatchewan and Alberta. Palaeontologisches Zentralblatt 9: 373. [Abstract].

1938a Rattlesnakes in Alberta. Canadian Geographical Journal 16(1): 33-41.

1938b New species of Gastropoda from the Oligocene of Colorado. Journal of Paleontology 12: 505-507. 
1938c Complete skull of a titanothere from the Lower Oligocene of Saskatchewan. Bulletin of the Geological Society of America 49: 1920. [Abstract].

1938d The skull of Hemipsalodon grandis, a giant Oligocene creodont. Proceedings of the Royal Society of Canada, Third Series, 32 (Appendix D): 146. [Abstract].

1938e Origin of the sandstone dykes of South-eastern Alberta. Proceedings of the Royal Society of Canada, Third Series, 32 (Appendix D): 146. [Abstract].

$1938 \mathrm{f}$ The skull of Hemipsalodon grandis, a giant Oligocene creodont. Transactions of the Royal Society of Canada, Third Series, 32 (Section 4): 61-66, Plates 1-5.

$1938 \mathrm{~g}$ New species of Gastropoda from the Oligocene of Colorado. Proceedings of the Geological Society of America for 1937: 288. [Abstract].

1938h Skull of Hemipsalodon grandis Cope. Proceedings of the Geological Society of America for 1937: 288. [Abstract].

1939a Land and sea movements in the Late Cretaceous of Western Canada. Proceedings of the Royal Society of Canada, Third Series, 33 (Appendix C): 198. [Abstract].

1939b Edmontonia rugosidens (Gilmore), an armoured dinosaur from the Belly River series of Alberta. Proceedings of the Royal Society of Canada, Third Series, 33 (Appendix C): 200. [Abstract].

1939c Land and sea movements in the Late Cretaceous of Western Canada. Transactions of the Royal Society of Canada, Third Series, 33 (Section 4): 81-99.

1939d Sclerotic ring in the skull of Lambeosaurus. Bulletin of the Geological Society of America 50: 1966. [Abstract].

1939e Notes on the occurrence of fossil fishes in the Upper Devonian of Maguasha, Quebec. Contributions of the Royal Ontario Museum of Palaeontology 2: 1-10, Plate 1.

1940a The sclerotic ring in the Hadrosauridae. Contributions of the Royal Ontario Museum of Palaeontology 3: 1-7, Plates 1-2.

1940b Studies of the Tertiary gravel deposits of Southern Saskatchewan. Proceedings of the Royal Society of Canada, Third Series, 34 (Appendix D): 158. [Abstract].

1940c Titanotheres from the Lower Oligocene Cypress Hills Formation of Saskatchewan. Proceedings of the Royal Society of Canada, Third Series, 34 (Appendix D): 159. [Abstract].

1940d Titanotheres from the Lower Oligocene Cypress Hills Formation of Saskatchewan. Transactions of the Royal Society of Canada, Third Series, 34 (Section 4): 89-100, Plates 1-5.

1940e Edmontonia rugosidens (Gilmore), an armoured dinosaur from the Belly River series of Alberta. University of Toronto Studies, Geological Series 43: 128, Plates I to VIII.

1940f Geology of the Southern Alberta plains. Part 1, Stratigraphy and structure. Geological Survey of Canada Memoir 221: 1-128, 3 maps.

1940g Micrichnus tracks from the Paskapoo Formation of Alberta. Transactions of the Royal Canadian Institute 23(49): 67-74, Plates 1-2.

1940 h Discovery of a marine fauna in Eastend Formation of Saskatchewan, Canada. Bulletin of the Geological Society of America 51: 1976.

1940i New genus of Gastropoda, probable ancestor of the Grangerellidae from the Upper Cretaceous of Alberta.
Bulletin of the Geological Society of America 51: 1976.

1941a Prograngerella, a new ancestral land snail from the Upper Cretaceous of Alberta. Journal of Paleontology 15 : 309-311.

1941b Pleistocene horse remains from Saskatchewan. Proceedings of the Royal Society of Canada, Third Series, 35 (Appendix C): 188. [Abstract].

1942a The structure of the crest in the dinosaur Parasaurolophus. Proceedings of the Royal Society of Canada, Third Series, 36 (Appendix C): 146. [Abstract].

1942b The application of geology to strategy and tactics. Proceedings of the Royal Society of Canada, Third Series, 36 (Appendix C): 146. [Abstract].

1943a Pleistocene horse teeth from Saskatchewan. Journal of Paleontology 17: 110-114.

1943b Marine fauna of the Eastend Formation of Saskatchewan. Journal of Paleontology 17: 281-288, Plates 47-49.

1946a The crest of the dinosaur Parasaurolophus. Contributions of the Royal Ontario Museum of Palaeontology 11: 1-5.

1946b Geophysical aspects of land-mine detection. Proceedings of the Royal Society of Canada, Third Series, 40 (Appendix C): 170. [Abstract].

1946c The lower jaw of the theropod dinosaur Troödon. Proceedings of the Royal Society of Canada, Third Series, 40 (Appendix C): 171. [Abstract].

1946d Preliminary report on the stratigraphy of the Gaspé limestone series, Forillon Peninsula, Cap des Rosiers township, County of Gaspé South. Province of Quebec Department of Mines, Bureau of Geological Surveys, Preliminary Report 195: 1-14.

1946e Rapport préliminaire sur la stratigraphie des séries de calcaires de Gaspé, péninsule de Forillon, canton de Cap des Rosiers, Comté de Gaspé Sud. Province de Québec, Ministère des Mines, Service de la Carte Géologique, Rapport préliminaire 195: 1-16 [French translation of above].

1947a Late Cretaceous and Early Tertiary correlation in Alberta and Saskatchewan. Bulletin of the Geological Society of America 58: 1223. [Abstract].

1947b Post-glacial mastodon remains from southwestern Ontario. Bulletin of the Geological Society of America 58: 1223. [Abstract].

1947c A new locality for fossil fishes and eurypterids in the Middle Devonian of Gaspé, Quebec. Contributions of the Royal Ontario Museum of Palaeontology 12: 1-6.

1948a A Middle Paleocene mammal tooth from the foothills of Alberta. American Journal of Science 246: 152156, Plate 1.

1948b The dentary of Troödon, a genus of theropod dinosaurs. Journal of Paleontology 22: 625-629.

1948c Post-glacial occurrence of mastodon remains in southwestern Ontario. Transactions of the Royal Canadian Institute 27(57): 57-64.

1948d Faunal facies in the Late Cretaceous marine deposits of western Canada. Bulletin of the Geological Society of America 59: 1348-1349. [Abstract].

1949a The relationships of the Alberta Cretaceous dinosaur "Laosaurus" minimus Gilmore. Journal of Paleontology 23: 518-520.

1949b Preliminary Report. The geology of the southern part of the Cypress Hills, southwestern Saskatchewan. 
Saskatchewan Geological Survey, Petroleum Geology Series 1: 1-56.

1950a Correlation of the Cretaceous-Tertiary transition in Saskatchewan and Alberta. Bulletin of the Geological Society of America 61: 27-42.

$1950 \mathrm{~b}$ The Tertiary gravels of Saskatchewan. Proceedings of the Royal Society of Canada, Third Series, 44 (Appendix F): 226. [Abstract].

1950c The Tertiary gravels of Saskatchewan. Transactions of the Royal Society of Canada, Third Series, 44 (Section 4): 51-59.

1951a Acanthodians of the Upper Devonian Escuminac Formation, Maguasha, Quebec. Annals and Magazine of Natural History, Series 12, 4: 401-407.

1951b Personalities in paleontology (Charles M. Sternberg). News Bulletin of the Society of Vertebrate Paleontology 31: 28-30.

1951c Bobasatrania? canadensis (Lambe), a giant chondrostean fish from the Rocky Mountains. Annual Report of the National Museum of Canada for the fiscal year 1949-50, Bulletin 123: 218-224, Plates 45-46.

1951d Age of the Front-Range deformation in the North American Cordillera. Proceedings of the Royal Society of Canada, Third Series, 45 (Appendix D): 201. [Abstract].

1951e Age of the Front-Range deformation in the North American Cordillera. Transactions of the Royal Society of Canada, Third Series, 45 (Section 4): 47-69.

$1951 f$ Land snails of the Cypress Hills and their significance. Canadian Field-Naturalist 65: 174-175.

1952a The Northeast Conference of the American Association of Museums, Cooperstown, New York, 19th \& $20^{\text {th }}$ October, 1951. Bulletin of the Canadian Museums Association 5(1): 7-12.

$1952 \mathrm{~b}$ Succession duties and museum bequests. Bulletin of the Canadian Museums Association 5(1): 13-14.

1952c Television and museums - an interim report. Bulletin of the Canadian Museums Association 5(1): 15-16.

1952d Out-of-doors museums. Bulletin of the Canadian Museums Association 5(2): 9-12.

1952e A new species of eurypterid from the Devonian of Gaspé. Proceedings of the Royal Society of Canada, Third Series, 46 (Appendix C): 149-150. [Abstract].

1952f Cretaceous mammals of Alberta. Annual Report of the National Museum of Canada for the fiscal year 1950-51, Bulletin 126: 110-119, Plates 14-15.

1952g Molluscan fauna of the Kishenehn Formation, Southeastern British Columbia. Annual Report of the National Museum of Canada for the fiscal year 1950-51, Bulletin 126: 120-141, Plates 16-19.

$1952 \mathrm{~h}$ Television and museums - second report. Bulletin of the Canadian Museums Association 5(4): 14-16.

1953a Gettysburg, a museum of fields and hillsides. Bulletin of the Canadian Museums Association 6(1): 10-12.

1953b Upper Cretaceous stratigraphy of southwestern Saskatchewan. Billings Geological Society, Guidebook, Fourth Annual Field Conference: 87-97.

1953c Tertiary stratigraphy of southwestern Saskatchewan. Billings Geological Society, Guidebook, Fourth Annual Field Conference: 106-113.

1953d Museum news bulletins. Bulletin of the Canadian Museums Association 6(2): 8-11.

1953e Fauna and age of the Kishenehn Formation, southeastern British Columbia. Proceedings of the Royal
Society of Canada, Third Series, 47 (Appendix C): 155. [Abstract].

1953f The new art gallery of Hamilton. Bulletin of the Canadian Museums Association 6(4): 4.

$1953 \mathrm{~g}$ Museums of applied science. Bulletin of the Canadian Museums Association 6(4): 5-7.

1953h The new Kwakiutl house of Thunderbird Park. Bulletin of the Canadian Museums Association 6(4): 7-8.

1954a A new species of eurypterid from the Devonian of Gaspé. Annual Report of the National Museum of Canada for the fiscal year 1952-53, Bulletin 132: 83-91, Plates 1-2.

1954b Mammalian fauna of the Kishenehn Formation, southeastern British Columbia. Annual Report of the National Museum of Canada for the fiscal year 1952-53, Bulletin 132: 92-111, Plates 1-3.

$1954 \mathrm{c}$ Evidence of tooth structure on the relationships of the early groups of Carnivora. Evolution 8: 166-171.

1954d The Eocene-Oligocene transition as a time of major orogeny in Western North America. Proceedings of the Royal Society of Canada, Third Series, 48 (Appendix C): 35. [Abstract].

1954e The Eocene-Oligocene transition as a time of major orogeny in Western North America. Transactions of the Royal Society of Canada, Third Series, 48 (Section 4): 65-69.

1954f A new species of Cephalaspis from the Devonian Gaspé sandstone at D'Aiguillon. Le Naturaliste Canadien 81: 245-254.

1955a Dutch painting - the golden age. Bulletin of the Canadian Museums Association 8(1): 1-3.

1955b Television and museums - third report. Bulletin of the Canadian Museums Association 8(1): 10-16.

1955c Opening of the new Saskatchewan museum. Bulletin of the Canadian Museums Association 8(2): 8.

1955d Fort Ticonderoga bicentenary. Bulletin of the Canadian Museums Association 8(2): 11-13.

1955e Age of the Princeton Group, southwestern British Columbia. Proceedings of the Royal Society of Canada, Third Series, 49 (Appendix C): 40. [Abstract].

$1955 \mathrm{f}$ Recollections of some Alberta museums. Bulletin of the Canadian Museums Association 8(3): 9-12.

1955g Additions to the molluscan fauna of the Kishenehn Formation, Southeastern British Columbia and adjacent Montana. Annual Report of the National Museum of Canada for the fiscal year 1953-54, Bulletin 136: 102-119, Plates 1-3.

1956a Plastics in the museum. Bulletin of the Canadian Museums Association 9(1): 10-15.

1956b Additional occurrences of fossil horse remains in western Canada. Annual Report of the National Museum of Canada for the fiscal year 1954-55, Bulletin 142: 153-154.

1956c New discoveries of Miocene vertebrates in Saskatchewan. Proceedings of the Royal Society of Canada, Third Series, 50 (Appendix C): 39. [Abstract].

1956d Nonmarine Mollusca from the North Park Formation of Saratoga Valley, Wyoming. Journal of Paleontology 30: 1260-1263.

1956e The National Museum of History, Mexico. Bulletin of the Canadian Museums Association 9(4): 15-16.

$1956 f$ The Cretaceous reptile Champsosaurus natator Parks. National Museum of Canada Bulletin 145: 1-51, Plates 1-12. 
1957a Tenth anniversary of the Canadian Museums Association. Bulletin of the Canadian Museums Association 10(1): 1-2.

1957b International Geophysical Year exhibit at the National Museum. Bulletin of the Canadian Museums Association 10(1): 8-12.

1957c One man's impressions of the Lincoln Nebraska meeting of the American Association of Museums. Bulletin of the Canadian Museums Association 10(2): 10-14.

1957d The eleventh annual meeting of the Northeast Museums Conference, Montreal and Quebec cities, September 3rd, 4th and 5th, 1957. Bulletin of the Canadian Museums Association 10(3): 1-5.

1957e Historical conservation along the St. Lawrence Seaway. Bulletin of the Canadian Museums Association 10(3): 7-9.

1957f Tertiary plains of Alberta and Saskatchewan. Proceedings of the Geological Association of Canada 9: 17-19.

1958a Mollusca from the Tertiary of Princeton, British Columbia. Annual Report of the National Museum of Canada for the fiscal year 1955-56, Bulletin 147: 84-95, Plates 1-2.

1958b Paleocene mammal teeth from Alberta. Annual Report of the National Museum of Canada for the fiscal year 1955-56, Bulletin 147: 96-103, Plate 1.

1958c Report on the annual meeting of the Canadian Museums Association, Windsor, Ontario, May 7th to 9th, 1958. Bulletin of the Canadian Museums Association 11(2): 3-15.

1958d Mammal teeth from the Edmonton Formation at Scabby Butte, Alberta. Proceedings of the Royal Society of Canada, Third Series, 52 (Appendix C): 24. [Abstract].

1958e A horse astragalus from the Hand Hills conglomerate of Alberta. National Museum of Canada, Natural History Papers 1: 1-3.

1958f A palaeontological view of convergence, parallelism and orthogenesis. XVth International Congress of Zoology, Section 1, Paper 24. [Abstract].

1959a The dentition of rabbits and the origin of the Lagomorpha. National Museum of Canada Contributions to Zoology for 1958, Bulletin 166: 41-45.

1959b Continental zoology of the North American Pleistocene. Problems of the Pleistocene and Arctic, Publications of the McGill University Museums 1(1): 39-45.

1959c Fossil mammals and intercontinental connections. Proceedings of the Royal Society of Canada, Third Series, 52 (Appendix C): 18. [Abstract].

1959d Darwin: the origin of species. Pamphlet to accompany an exhibit at the National Museum of Canada celebrating the 100th anniversary of the publication of "The Origin of Species". 3 pages.

1960a The geological record of evolution. Pages 3-11 in Evolution: Its Science and Doctrine. Edited by T. W. M. Cameron. University of Toronto Press, Toronto.

1960b Fossil mammals and intercontinental connections. Pages 63-78 in Evolution: Its Science and Doctrine. Edited by T. W. M. Cameron. University of Toronto Press, Toronto.

1961a The National Museum of Canada 1910 to 1960. Department of Northern Affairs and National Resources, Ottawa. 37 pages.

1961b A museum for Canadians. Annual Report for 196061, Department of Northern Affairs and National Resources, 13 pages. 1961c Swinton to ROM. Bulletin of the Canadian Museums Association 13(4): 5.

1962a Mammalian migrations in the Pleistocene. Problems of the Pleistocene and Arctic, Publications of the McGill University Museums 2(2): 48-55.

1962b Mammal teeth from the St. Mary River Formation (Upper Cretaceous) at Scabby Butte, Alberta. National Museum of Canada, Natural History Papers 14: 1-4.

1962c Rudolph Martin Anderson. Canadian Geographical Journal 45(6): 198-199.

1963a Problems and potentialities of the history museum. Curator 6: 341-349.

1963b Canadian museums - this centenary and the next. Bulletin of the Canadian Museum Association 14(4): 8-14.

1964a Kishenehn Formation. Bulletin of Canadian Petroleum Geology 12: 536-543.

1964b Cretaceous non-marine faunas of northwestern North America. Royal Ontario Museum Life Sciences Contribution 61: 1-24.

1964c The coming of kerosene. The Rushlight 30(2): 3-6.

1965a The problem of the Willow Creek Formation. Canadian Journal of Earth Sciences 2: 11-14.

1965b Pushing back the dawn. Meeting Place, Journal of the Royal Ontario Museum 1(3): 82-87.

1965 c Body temperature of dinosaurs and its relationships to their extinction. Journal of Paleontology 39: 497-501.

1965d Alice Evelyn Wilson, 1881-1964. Canadian FieldNaturalist 79: 159-161.

1965e Frank Harris McLearn, 1885-1964. Proceedings of the Royal Society of Canada, Fourth Series, 3: 135139.

$1965 f$ The mastodon. Royal Ontario Museum "What? Why? When? How? Where? Who?" 6: 1-16.

$1965 \mathrm{~g}$ Tertiary mammals of Saskatchewan, Part I: The Eocene fauna. Royal Ontario Museum Life Sciences Contribution 67: 1-33, Plates 1-7.

1965h W. A. Clemens and L. S. Russell. Mammalian fossils from the Upper Edmonton Formation. Pages 32-40 in Vertebrate Palaeontology in Alberta. Report of a Conference held at the University of Alberta, Aug. 29-Sept. 3, 1963. University of Alberta, Edmonton.

1965i The continental Tertiary of Western Canada. Pages 41-52 in Vertebrate Palaeontology in Alberta. Report of a conference held at the University of Alberta Aug. 29 to Sept. 3, 1963. University of Alberta, Edmonton.

1965j Macropalaeontology of the surface formations, Cypress Hills area, Alberta and Saskatchewan. Alberta Society of Petroleum Geologists, 15th Annual Field Conference Guide Book, Part 1, Cypress Hills Plateau: 131-136.

1966a A Paleocene conglomerate in westcentral Alberta. Canadian Journal of Earth Sciences 3: 127-128.

1966b Dinosaur hunting in western Canada. Royal Ontario Museum Life Sciences Contribution 70: 1-37.

1966c The changing environment of the dinosaurs in North America. The Advancement of Science, 23(110): 197-204.

1966d Palaeontology of the Swan Hills area, north-central Alberta. Transactions of the Royal Society of Canada, Fourth Series, 4 (Appendix): 16. [Abstract].

1966e Exploring the "New Red Sandstone". Meeting Place, Journal of the Royal Ontario Museum 1(8): 105-107.

$1966 f$ Lighting the pioneer Ontario home. Royal Ontario Museum "What? Why? When? How? Where? Who?" 12: 1-16. 
1966g More heat than light. The Rushlight 32(2): 1-4.

1967a Palaeontology of the Swan Hills area, north-central Alberta. Royal Ontario Museum Life Sciences Contribution 71: 1-31, Plate 1.

1967b Comment on: The inability of dinosaurs to hibernate as a possible key factor in their extinction, by J. M. Cys. Journal of Paleontology 41: 267.

1967c Confederation lamps. Canadian Antiques Collector 2(3): 9-11.

1967d Review of: Fossil mammals of the type Lance Formation of Wyoming, Part II: Marsupialia by W. A. Clemens. Journal of Paleontology 41: 813-814.

1967e Review of: Marsh's Dinosaurs: The collections from Como Bluffs by J.H. Ostrom and J.S. McIntosh. Journal of Paleontology 41: 1029-1030.

1967f Unionidae from the Cretaceous and Tertiary of Alberta and Montana. Journal of Paleontology 41: 11161120.

1967g A pedunculate cirripede from Upper Cretaceous rocks of Saskatchewan. Journal of Paleontology 41: 15441547.

1968a A dinosaur bone from Willow Creek beds in Montana. Canadian Journal of Earth Sciences 5: 327-329.

1968b A new cetacean from Oligocene Sooke Formation of Vancouver Island. Canadian Journal of Earth Sciences 5: 929-933, Plates 1-2.

1968c A Heritage of Light. University of Toronto Press, Toronto. 344 pages.

1969a Banquet lamp from the 1870s - a correction. Ontario Showcase 34(4): 6-7.

1969b Adventures in old-time lighting. Rotunda 2(1): 16-25.

1970a The great Saskatchewan Mouse Mine. Rotunda 3(1): 16-24.

1970b Can we neglect research? Museum News 48(6): 1314,48 .

1970c Correlation of the Upper Cretaceous Montana Group between southern Alberta and Montana. Canadian Journal of Earth Sciences 7: 1099-1108.

1971 Those remarkable dinosaurs. Rotunda 4(1): 4-17.

1972a L. S. Russell and C. S. Churcher. Vertebrate palaeontology, Cretaceous to Recent, Interior Plains, Canada. XXIV International Geological Congress (Montreal, Canada), Field Excursion Guidebook 24, Part A21: 1-46.

1972b Tertiary mammals of Saskatchewan, Part II: The Oligocene fauna, non-ungulate orders. Royal Ontario Museum Life Sciences Contributions 84: 1-97.

1972c Report of the President. Proceedings of the Royal Canadian Institute, Series 5, 19: 2-5.

1972d The fifty million year pedigree of the horse. Proceedings of the Royal Canadian Institute, Series 5, 19: 6-15.

1973a Geological evidence on the extinction of some large terrestrial vertebrates. Canadian Journal of Earth Sciences 10: 140-145.

1973b Everyday Life in Colonial Canada. Copp Clark Publishing Company, Toronto. 207 pages.

1973c Erratum: Geological evidence on the extinction of some large terrestrial vertebrates. Canadian Journal of Earth Sciences 10: 1361.

1974a R. E. Sloan and L. S. Russell. Mammals from the St. Mary River Formation (Cretaceous) of southwestern Alberta. Royal Ontario Museum Life Sciences Contribution 95: 1-21.

1974b Fauna and correlation of the Ravenscrag Formation (Paleocene) of southwestern Saskatchewan. Royal
Ontario Museum Life Sciences Contribution 102: 153.

1974c Tools of the Trades. Pages 227-239 in The Book of Canadian Antiques. Edited by D. B. Webster. McGrawHill Ryerson, Toronto.

1974d Review of: Cars of Canada by H. Durnford and G. Baechler. Canada: An Historical Magazine 2(1): 59-60.

1975a Lower Cretaceous non-marine fauna of Alberta and Montana. Geological Society of America, Abstracts with Programs 7(6): 847. [Abstract]

1975b Revision of the fossil horses from the Cypress Hills Formation (Lower Oligocene) of Saskatchewan. Canadian Journal of Earth Sciences 12: 636-648, Plates 1-6.

1975c Mammalian faunal sucession in the Cretaceous system of Western North America. Pages 137-161 in W. G. E. Caldwell (editor), The Cretaceous System in the Western Interior of North America. Geological Association of Canada Special Paper 13.

1975d "Carbide" Willson. Canada: An Historical Magazine 3(1): 20-33.

1975e The first Canadian cooking stove. Canada: An Historical Magazine 3(2): 34-35.

1976a Pelecypods of the Hell Creek Formation (Uppermost Cretaceous) of Garfield County, Montana. Canadian Journal of Earth Sciences 13: 365-388, Plates 1-7.

1976b The image of palaeontology. Pages 14-17 in Athlon: Essays in Honour of Loris Shano Russell. Edited by C. S. Churcher. Royal Ontario Museum Life Sciences Miscellaneous Publication.

1976c The palaeogeographic significance of the polyprotodont marsupials. XXVth International Geological Congress, Sydney, Australia, Abstracts 1(7C): 333334. [Abstract].

1976d A new species of talpid insectivore from the Miocene of Saskatchewan. Canadian Journal of Earth Sciences 13: 1602-1607.

1976e Early nineteenth-century lighting. Pages 186-201 in Building early America: contributions toward a history of a great industry. Edited by C. E. Peterson. Chilton Books Company, Radnor, Pennsylvania.

1976f Early Canadian sewing machines. Canadian Collector 11(5): 26-29.

1977 L. S. Russell and G. Edmund. Obituary: Levi Sternberg, 1894-1976. News Bulletin of the Society of Vertebrate Paleontology 110: 43-44.

1978 Tertiary mammals of Saskatchewan, Part IV: The Oligocene anthracotheres. Royal Ontario Museum Life Sciences Contributions 115: 1-16.

1979 Handy Things to Have Around the House. McGrawHill Ryerson Limited, Toronto. 176 pages.

1980a Tertiary mammals of Saskatchewan, Part V: The Oligocene entelodonts. Royal Ontario Museum Life Sciences Contributions 122: 1-42.

1980b A new species of Brachyhyops? (Mammalia, Artiodactyla) from the Oligocene Cypress Hills Formation of Saskatchewan. Royal Ontario Museum Life Sciences Occasional Paper 33: 1-8.

1980c Alf Erling Porsild 1901-1977. Proceedings of the Royal Society of Canada, Fourth Series, 18: 111-114.

$1980 \mathrm{~d}$ Invention and discovery/Invention et découverte: the role of the inventor in Canada and the use of the patent office records. Pages 120-128 in Science, Technology, and Canadian History. Edited by R. A. Jarrell and N. R. Ball. Wilfrid Laurier University Press, Waterloo, Ontario. 
1982a Tertiary mammals of Saskatchewan, Part VI: The Oligocene rhinoceroses. Royal Ontario Museum Life Sciences Contributions 133: 1-58.

1982b Charles Mortram Sternberg, 1885-1981. News Bulletin of the Society of Vertebrate Paleontology 124: 70-72.

1982c Charles Mortram Sternberg, 1885-1981. Canadian Field-Naturalist 96: 483-486, and cover photograph.

1982d Charles Mortram Sternberg, 1885-1981. Proceedings of the Royal Society of Canada, Fourth Series, 20: $132-135$.

1983 Evidence for an unconformity at the Scollard-Battle contact, Upper Cretaceous strata, Alberta. Canadian Journal of Earth Sciences 20: 1219-1231.

1984a Tertiary mammals of Saskatchewan, Part VII: Oligocene marsupials. Royal Ontario Museum Life Sciences Contributions 139: 1-13.

1984b Bringing them back alive. Rotunda 17(2): 12-17.

1986 Exploring a great dinosaur graveyard. Rotunda 19(2): 20-29.

1987a Biostratigraphy and palaeontology of the Scollard Formation, Late Cretaceous and Paleocene of Alberta. Royal Ontario Museum Life Sciences Contributions 147: 1-23.

1987 b R. J. Emry, L. S. Russell and P. R. Bjork. The Chadronian, Orellan, and Whitneyan North American land mammal ages. Pages 118-152 in Cenozoic Mammals of North America: geochronology and biostratigraphy. Edited by M. O. Woodburne. University of California Press, Berkeley.

1988 The first fossil hunters. Alberta 1(1): 11-16.

1989 Preface. Pages 1-2 in Geological History of Saskatchewan by J. Storer. Saskatchewan Museum of Natural History, Regina. 90 pages.

1990a Thomas Chesmer Weston and the Red Deer River fossil fields. Earth Sciences History 9(1): 3-5.

1990b Charles Mortram Sternberg and the Alberta dinosaurs. Pages ix-xiii in Dinosaur Systematics: Approaches and Perspectives. Edited by K. Carpenter and P. J. Currie. Cambridge University Press, Cambridge.

1993 D. F. Stott, J. Dixon, J. R. Dietrich, D. H. McNeil, L. S. Russell, and A. R. Sweet. Tertiary. Pages 439465 in Sedimentary Cover of the Craton in Canada. Edited by D. F. Stott and J. D. Aiken. Geological Survey of Canada, Geology of Canada 5.

2003 A Heritage of Light. University of Toronto Press, Toronto. 344 pages. [reprint of 1968 volume].

unpublished Biostratigraphy of the Horseshoe Canyon Formation, Edmonton Group, Upper Cretaceous of Alberta. Unpublished manuscript on file at ROM. 